\title{
Maintaining food security during difficult times: An experience of COVID-19 in Kerala
}

Rajeev Jayalakshmi MPH

Central University of Kerala

Srinivasan Kannan PhD ( $\nabla$ kannansrini@ymail.com )

Sree Chitra Tirunal Institute for Medical Sciences and Technology, https://orcid.org/0000-0003-27319428

\section{Short Report}

Keywords: Food security, COVID-19, Inclusivity, Interventions, Kerala

Posted Date: September 1st, 2021

DOl: https://doi.org/10.21203/rs.3.rs-864547/v1

License: (1) (1) This work is licensed under a Creative Commons Attribution 4.0 International License. Read Full License 


\section{Abstract}

Lockdown linked to the COVID-19 pandemic generated food security associated panic among the general population. This article is an exercise to document actions taken by the Government of Kerala to prevent people from starving during such difficult times of lockdown. Inclusive interventions such as provision of dry ration free of cost, operating community kitchens and engaging in direct cash transfers were some of the highlights of the measures taken by the Government in Kerala to address the food crisis in the state. These efforts are evidence for the government's commitment towards managing the crisis and this was possible through the involvement of effective decentralized governance through local self-government institutions and community organizations.

\section{Introduction}

Food security is the physical and economic access of all people at all times to sufficient food to meet their dietary needs for productive and healthy lives. ${ }^{1}$ It depends on four main pillars, food availability (enough food for the entire population available physically), food access (households have enough resources, such as land, money, or social connections, to obtain nutritious foods in adequate amounts), food utilization (how people's bodies use the food they eat.) and stability (access to adequate food at all times). ${ }^{1}$ Food security of a community is in crisis when any or all of these pillars face a menace. The COVID-19 pandemic is one such threat that severely impacted the economy of many of the affected countries similar to earlier ones as the influenza pandemic in 1930s.

The first positive case of COVID-19 was reported in Kerala, a southern state of India, on 27 January 2020. With experience of controlling the Nipah epidemic in the recent past and addressing post national calamities such as floods during 2018 and 2019, the state responded timely in containing the spread of the virus. ${ }^{2,3}$ The state's timely interventions were successful in terms of containing the spread of the virus to a great extent and were greatly appreciated across the world. ${ }^{2,3}$ However, the pandemic was a big assault on the economy of the state which is primarily tertiary sector-based and witnessed two floods consequently in the last two years. ${ }^{4}$ The call for complete lockdown during the month of March 2020 was seen as an unexpected call to contain the disease by the Government of India that left many people without an income, challenging their sustenance. In this situation, the state government intervened with number of initiatives to ensure that people were not starving due to the unexpected situation.

\section{Food security threat from COVID-19}

The complete lockdown called post COVID-19 disrupted the economic activities in Kerala as experienced by the rest of the country. ${ }^{4}$ Kerala is primarily a consumer state, which depends on other states for most of the food products including rice, the staple food. The lockdown led to closing of the state borders with two adjacent states interrupting the transportation of food commodities to the state. This resulted in the reduction of food availability at the ground level. The food access also compromised as many people were left without sufficient disposable income due to loss of jobs and complete shutdown of transportation. This 
is how the basic two pillars of the food security namely, availability and access, have been affected and these two are the first signs of food security crisis in a community. Consequently, the state government of

Kerala has responded proactively anticipating further problems in food security and ensured sufficient food for all in the state. This paper discusses such strategies of the Government of Kerala to ensure food security during the lockdown period.

\section{Methods}

In this paper, we did a document analysis of the ordinances, guidelines and notifications published by the Government of Kerala to various departments, agencies and public, as a response to tackle abovementioned food security threats during the lock-down period after the incidence of COVID-19 Pandemic. The documents published from 20th March 2020 to 31st May 2020 were analysed focusing on measures to ensure food security of people. The major themes emerged are discussed below.

\section{Results}

\section{The gearing up to ensure food for all}

The government order dated 20th March 2020 listed out the responsibilities of local self-government institutions (LSGIs) ${ }^{a}$ for the purposes of addressing problems arising out of COVID-19. The order specified that the LSGIs in collaboration with Food and Civil Supplies Department should ensure the sufficient availability of essential food items to all. LSGIs also needed to take necessary measures to prevent hoarding and control black-marketing of goods by the way of engaging in strict monitoring mechanisms. Further, the order directed the LSGIs to focus more on the vulnerable sections of the society that included differently abled; pregnant women; scheduled caste and scheduled tribe population; slum dwellers and people live in coastal areas; inmates of care homes; migrant labourers, and labourers under National Rural Employment Guarantee Scheme ${ }^{\text {b }}{ }^{5}$

The extraordinary notification based on the Kerala Essential Service Maintenance Act, 1994 published in the government gazette on 25th of March 2020, notified that processing, procurement, storage, transportation and supply of food items are essential services. This notification enabled the goods vehicles to cross the borders of Kerala and ensured the supply of food and other essential items. The Food and Civil Supplies Department was entrusted with the responsibility of monitoring the procurement and distribution of locally produced food items. The shops/stores/supermarkets that sold food items such as rice, wheat, fresh fruits and vegetables, other grocery items, milk, meat, fish and egg were allowed to open daily at specific opening times, excluding Sundays which was total lockdown day. ${ }^{6}$

The government of Kerala acted on war footing for ensuring access to food items. First, people with the ration card under the Public Distribution System ${ }^{\mathrm{c}}$ such as Antyodaya Anna Yojana (AAY) ${ }^{\mathrm{C}}$ cardholders and Priority Household $(\mathrm{PHH})^{\mathrm{C}}$ cardholders were provided with the free ration for the full monthly entitlement of 
April 2020. Along with that non-priority cardholders ${ }^{c}$ were given 15 kilograms of rice free. And those households without any ration card were also provided with free ration during April 2020. ${ }^{7}$

Simultaneously, the government was operating community kitchens with the assistance of the Kudumbashree Mission ${ }^{d}$ and local self-government institutions. The guidelines released by the government of Kerala on 26th March 2020 has given detailed protocol for the community kitchens. About INR 236.4 million was released from the budget allocated for Kudumbashree mission from the current financial year (2020-2021) for this purpose. Already functioning restaurants under Kudumbashree units and kitchens that were available at schools, auditoriums, and other premises were also utilised for this purpose. According to the guidelines, each community kitchen was created to serve food to 500 to 1000 people in a designated area. The local self-government institutions were also been issued with the directive that clearly mentioned the modalities for ensuring distribution of food to poor households, destitute and immobile bedridden population. The kitchens were also allowed to generate support in both cash and kind for their operations. In the event of insufficient funds or goods for operating their kitchens, they might approach LSGIs and were supported by the annual plan fund. The food was packaged and the rapid response teams available at the grass root level for emergency response distributed them. In addition, other members of the community (excluding elderly and children) were also volunteering for the distribution of the food strictly adhering the personal hygiene and social distancing as per the guidelines. It was also noted that they were asked to include at least one food item prepared based on locally available green leafy vegetable on their menu. The meals were distributed freely to economically weaker sections and were sold at a price of INR 20 for others members. This has become a model for other states in establishing community kitchens across the country. ${ }^{8}$

\section{Inclusivity}

Special attention was given to ensure food for inmates of elderly homes, orphanages, and for migrant labourers (also referred as guest workers in the government documents). The state government directed the LSGIs to ensure the availability of food either by providing essential items required to cook food at the migrant labourers' homes or distributing already prepared meals from community kitchens. ${ }^{9,10}$

The Department of Women and Child Development was directed to provide the supplementary food to children and other beneficiaries served by Anganwadi centres ${ }^{e}$ under Integrated Child Development Services programme $e^{e}$ as per the order dated 23 rd March 2020. Around 850,000 children below six years, 200,000 adolescents and 300,000 are served under the programme across the state. Anganwadi workers, the frontline service providers of the programme were directed to distribute the fortified nutrimix for children of age six to 36 months and raw food grains in the specified quantities to all beneficiaries at their respective homes.

In the later stage of lockdown, all ration cardholders were given free kits with essential food items distributed through the fair price shops. The food kit included food items such as rice, Atta (wheat flour), pulses, spices and oil. The AAY cardholders were given the food kits first, followed by the priority cardholders, non-priority state subsidy ${ }^{\mathrm{C}}$ cardholders and non-priority non-state subsidy ${ }^{\mathrm{C}}$ cardholders. ${ }^{11}$ Even 
before the start of lockdown, free food kits were distributed to households with members under observation or undergoing quarantine. In addition to the measures to ensure food security, the government has immediately released of social security pensions including the arrears that benefitted old age people, eligible widows and those who were unemployed and disabled. The direct transfer of INR 1000 (\$13.23) was provided to below poverty line households, and workers in the informal sector who were not able to work during the lockdown. ${ }^{12}$

\section{Challenges in implementation}

The implementation of any of these interventions was not without facing challenges. In the initial phase, the government has to strongly intervene to prevent the price inflation of food items due to hoarding. ${ }^{13}$ The difficulty of getting volunteers was also reported due to the fear of contracting the disease. Moreover, the spread of the disease in districts bordering other states led to conflicts with the respective states limiting the entry of food items within the local markets of Kerala. ${ }^{14}$ However, strong political commitment from the side of both ruling and opposition parties has helped to overcome this problem. Timely disbursal of the declared services was also a challenge as most of the delivery points including government offices were working with limited human resources. The food kit distribution also faced challenges as the goods movements were affected during the lockdown period. ${ }^{15}$

Further, the disbursal of supplementary nutrition to ICDS beneficiaries at their home were experiencing challenges. During follow-up calls that the researcher made by contacting the Anganwadi workers, it was learned that house to house delivery was burdensome as they had no transportation facilities and had to carry the baggage while walking during the house visits. Hence, they invited the family members of the beneficiaries on specific dates to the food grains. The duration of distribution varied from once in 15 days to once a month. AWWs directly distributed the grains to beneficiaries who resided in the vicinity. It was difficult to ensure whether the beneficiary received the entitled amount of supplementary nutrition or it was shared with other members of the family. Regular monitoring of growth by taking height and weight of the children was not happening due to restrictions during lockdown period. It is important to reinstate the height and weight monitoring immediately in the light of consistent alerts on impact of COVID-19 on child malnutrition by the United Nation's Children's Fund's (UNICEF) and World Health Organizations'. ${ }^{16,17}$

\section{Conclusion}

Inclusivity is the keystone of all these interventions. By placing the vulnerable sections of the society in front of availing the benefits of all the measures, the government ensured that no individual or household was left behind. The strongly decentralized system of governance at the ground level enabled the government to reach to all sections of the community.

The above-mentioned actions taken by the state were intended to provide immediate relief for people affected by lockdown. However, Kerala, anticipating a food insecurity crisis in the near future in consequent to the economic crisis due to COVID-19 in India, is proactively planning programmes to ensure self- 
sufficiency in food production. The government plans to take up the unused land across the state mainly to cultivate vegetables under the scheme known as 'Subhiksha Keralam' ${ }^{\prime}{ }^{18,19}$

Kerala has been already a model for other states and the country with its effective interventions to contain COVID-19. The measures taken by the state to prevent the food security crisis is another example of how Kerala walks in front of other states in India. However, it is not without flaws, which need to be addressed urgently to reach to all needy, especially, children.

\section{Illustrations}

a - Local Self Government Institutions are the administrative bodies of a small community such as a village, a town or a city.

b - Mahatma Gandhi National Rural Employment Guarantee Scheme is a social security measure of the Government of India to ensure Right to work of citizens

c - Public Distribution System is the Government of India's flagship programme to ensure Food Security. Free or subsidized rice and wheat are given to people whom were categorised into four in Kerala, based on their economic status. The categories are 1) Antyodaya Anna Yojana (AAY) - most economically backward section, 2) Priority households $(\mathrm{PHH})$ - below poverty line households with monthly income less than $\$ 330.65,3)$ Non-priority state subsidy households- monthly income more than $\$ 330.65$ and avail state subsidy, 4) Non-priority, non- state subsidy households -economically better section.

$d$-Kudumbashree Mission is the poverty eradication and women empowerment programme implemented by the Government of Kerala. Women run it as self-help groups.

e - Integrated Child development Services programme ensure nutrition security of children of age 0-6 years, adolescent girls and pregnant and lactating mothers in India. The services are provided at the ground level through Anganwadi centres.

$f$ - Subhiksha Keralam is the flagship programme of Government of Kerala to ensure food self-sufficiency.

\section{Declarations}

Conflicts of Interest:

None to be declared.

\section{Acknowledgements:}

Nil

Source of funding: Nil 


\section{References}

1. Food and Agriculture Organization (FAO). Food Security [Internet]. 2006 [cited 2020 Jun 5]. Available from:

http://www.fao.org/fileadmin/templates/faoitaly/documents/pdf/pdf_Food_Security_Cocept_Note.pdf

2. Kurian OC. How the Indian state of Kerala flattened the coronavirus curve I Opinion I The Guardian [Internet]. The Guardian. 2020 [cited 2020 Jun 5]. Available from:

https://www.theguardian.com/commentisfree/2020/apr/21/kerala-indian-state-flattened-coronaviruscurve

3. Biswas S. Coronavirus: How India's Kerala state "flattened the curve" - BBC News [Internet]. BBC News. 2020 [cited 2020 Jun 5]. Available from: https://www.bbc.com/news/world-asia-india-52283748

4. Harikrishnan C. Lockdown impact on kerala economy: Kerala estimates Q1 loss of Rs 80,000 crore to GVA [Internet]. 2020 [cited 2020 Jun 5]. Available from: https://economictimes.indiatimes.com/news/economy/indicators/covid-lockdown-impact-keralaestimates-q1-loss-of-rs-80000-crore-to-gva/articleshow/75601314.cms?from=mdr

5. Government of Kerala. Local Self-Government Department - Activities and Responsibilities of Local Self Government Institutions related to Covid Prevention in the State - Government Order [Internet]. 2020 [cited 2020 Jun 5]. Available from: https://kila.ac.in/sitedoc/documents/misc/covid19/GOCircular/1.\%20LSGD/2\%20G0\%2055\%20LSGD\%2020\%2003\%2020.pdf

6. Government of Kerala. Extraordinary Gazette Notification [Internet]. 2020 [cited 2020 Jun 5]. Available from: https://kila.ac.in/sitedoc/documents/misc/covid19/GO-

Circular/5.\%20HD/GO(P)\%2016\%20Home\%20Dept\%2025\%2003\%2020.pdf

7. Government of Kerala. Food, and Civil Supplies Department -COVID-19 Free Ration - related [Internet]. 2020 [cited 2020 Jun 5]. Available from: https://tpms.kila.ac.in/uploads/1589176577.pdf

8. Government of Kerala. Establishment of Community Kichen -Recommendations -Government Order [Internet]. 2020 [cited 2020 Jun 5]. Available from:

https://kila.ac.in/sitedoc/documents/misc/covid19/GO-

Circular/1.\%20LSGD/C\%205\%20Crcular\%2001\%2071\%20LSGD\%2028\%2003\%2020.pdf

9. Government of Kerala. Food and Civil Supplies Department - Ensuring food access to inmates of destitite homes, orphanages, childhomes, oldage homes and hospitals [Internet]. 2020 [cited 2020 Jun 5]. Available from: https://kila.ac.in/sitedoc/documents/misc/covid19/GO-

Circular/12.\%20FCS/Dest.pdf

10. Government of Kerala. panchayat Department - Covid prevention steps - Running of Community Kitchens [Internet]. 2020 [cited 2020 Jun 5]. Available from: https://kila.ac.in/sitedoc/documents/misc/covid19/GO-Circular/1.\%20LSGD/LSGDKudumbasree1.PDF

11. Government of Kerala. Food Kit to all households [Internet]. 2020 [cited 2020 Jun 5]. Available from: https://kila.ac.in/sitedoc/documents/misc/covid19/GO-Circular/12.\%20FCS/Food\%20Materials\%20\%20Kit.pdf 
12. The Kerala way of tackling a pandemic [Internet]. The Times of India. 2020 [cited 2020 Jun 5]. Available from: https://timesofindia.indiatimes.com/city/kochi/the-kerala-way-of-tackling-apandemic/articleshow/74709922.cms

13. Prices of vegetables soar in Kerala amid COVID-19 lockdown [Internet]. OnManorama. [cited 2020 Jun 5]. Available from: https://english.manoramaonline.com/news/kerala/2020/03/28/price-risevegetables-coronavirus-lockdown.html

14. Joseph AT. Hostility between states amid the COVID-19 pandemic hits trade, spurs food inflation fears [Internet]. The Caravan. [cited 2020 Jun 5]. Available from: https://caravanmagazine.in/economy/hostility-between-states-amid-the-covid-19-pandemic-hits-tradespurs-food-inflation-fears

15. Ration provisions kit to be delayed as goods movement affected in lockdown [Internet]. Mathrubhumi. [cited 2020 Jun 5]. Available from: https://english.mathrubhumi.com/news/kerala/ration-provisionskit-to-be-delayed-as-goods-movement-affected-in-lockdown-1.4661496

16. WHO EMRO. Feeding babies and young children during the COVID-19 outbreak [Internet]. 2020 [cited 2020 Aug 12]. Available from: http://www.emro.who.int/nutrition/nutrition-infocus/feeding-babies-andyoung-children-during-the-covid-19-outbreak.html

17. UNICEF, World Food Programme. Supporting children's nutrition during the COVID-19 pandemic [Internet]. 2020 [cited 2020 Aug 12]. Available from:

https://www.unicef.org/media/68521/file/Supporting-children\%E2\%80\%99s-nutrition-during-COVID-192020.pdf

18. Sebastian S. COVID-19 makes Kerala aim for food self-sufficiency [Internet]. DownToEarth. 2020 [cited 2020 Jun 5]. Available from: https://www. downtoearth.org.in/news/food/covid-19-makes-kerala-aimfor-food-self-sufficiency-70787

19. Government of Kerala. Subhiksha Keralam- Government Order [Internet]. [cited 2020 Jun 5]. Available from: https://www.nregs.kerala.gov.in/images/daily/2020-21/june/04.06.2020/1009.pdf 